\title{
Chromosome Abnormalities in Patients Treated with Chlorpromazine, Perphenazine, and Lysergide
}

\author{
J. NIELSEN,* M.D. ; U. FRIEDRICH, $\dagger$ M.D. ; T. TSUBOI, $\ddagger$ M.D.
}

Summary : In a chromosome study on leucocyte cultures $\checkmark$ made in 13 patients treated with chlorpromazine, 15 treated with perphenazine, and nine treated with lysergide, a significantly higher frequency of gaps, breaks, and hypodiploid cells in the patients treated with perphenazine and lysergide occurred compared with the 41 controls studied. It is concluded that if some drugs can induce major chromosome abnormalities, and less toxic alternatives are available, the latter should be used in preference.

\section{Introduction}

In a recent report (Nielsen et al., 1968b) we presented the findings of an increased frequency of gaps and breaks in the chromosomes of 17 psychiatric patients treated with different psychotropic drugs compared with those of 13 not treated with psychotropic drugs.

In this study a chromosome analysis was made of leucocyte cultures from 28 patients treated with only one psychotropic drug, and from a control group of 41 subjects.

\section{Material and Methods}

The 48-hour cultures from the patients treated with psychotropic drugs were randomly mixed and analysed "blind." Of the 28 patients 13 had been treated with chlorpromazine, 15 with perphenazine and an anti-Parkinsonian drug, orphenadrine (which was given to reduce the extrapyramidal side-effects of perphenazine), and nine with lysergide (Table I). Ten patients who were taking lysergide for psychedelic purposes and were admitted to a mental hospital on account of drug abuse were also studied. Several of these patients had taken lysergide only a few times, while only a few had taken it regularly. The amount of lysergide and the period over which they had taken it are not known. At the time of the chromosome analysis all of the patients treated with chlorpromazine and perphenazine were receiving these drugs, while those who had been taking lysergide were not. The control group consisted of 20 subjects from the hospital staff who were not taking any drugs, and 21 patients who were not being treated with psychotropic drugs. We did not divide our controls into hospital staff and hospital patients because we found no significant difference in the frequency of chromosome abnormalities between the two groups, nor any difference in the frequency of these abnormalities among female or male controls. Consequently we put all the controls below the age of 50 into one group and those aged 50 and over into another, as otherwise there would be several small groups.

Some of the cultures from the control group were 72-hour cultures. We found, however, no difference in the frequency of gaps, breaks, aneuploid cells, or any chromosome abnormality between the groups who had a 48-hour culture and those who

* Chief of Service.

† Clinical Assistant.

The Cytogenetic Laboratory, Arhus State Hospital, Risskov, Denmark. had a 72-hour culture. Court Brown et al. (1966), who made a careful study of the frequency of aneuploid cells in 48-hour and 72-hour cultures, found no significant difference, but only a tendency to a higher frequency of aneuploid cells in the 72hour cultures. If there is any difference in the frequency of chromosome abnormalities in question between 72-hour and 48-hour cultures this tends to be in the direction that there are slightly more pronounced abnormalities in 72-hour cultures, but the difference in the chromosome abnormalities between the two cultures is not statistically significant.

The difference in frequency of chromosome abnormalities between patients treated with psychotropic drugs and the controls was statistically tested with the $\chi^{2}$ test or the Fisher's exact test, and the results have been mentioned only if statistically significant (Tables II and III). The total number of chromosome abnormalities has been calculated in percentage of the total number of cells.

TABLE III.-Controls and Patients Treated with Chlorpromazine, Perphenazine, and Lysergide. Distribution by Dicentric Chromosomes, Ring Chromosomes, Fragments, and Cells Examined

\begin{tabular}{c|c|c|c|c|c|c|c}
\hline & $\begin{array}{c}\text { Di- } \\
\text { centric } \\
\text { chromo- } \\
\text { somes }\end{array}$ & $\begin{array}{c}\text { Ring } \\
\text { chromo- } \\
\text { somes }\end{array}$ & $\begin{array}{c}\text { Centric } \\
\text { frag- } \\
\text { ments }\end{array}$ & $\begin{array}{c}\text { Acentric } \\
\text { frag- } \\
\text { ments }\end{array}$ & Total & $\begin{array}{c}\text { Per- } \\
\text { centage } \\
\text { of cells } \\
\text { total }\end{array}$ & $\begin{array}{c}\text { Cells } \\
\text { total }\end{array}$ \\
\hline $\begin{array}{c}41 \text { controls } \\
13 \text { patients treated } \\
\text { with chlorpro- } \\
\text { mazine }\end{array}$ & 0 & 0 & 0 & 2 & 2 & $0 \cdot 1^{*} \dagger$ & 1,584 \\
$\begin{array}{c}15 \text { patients treated } \\
\text { with perphena- } \\
\text { azine }\end{array}$ & 2 & 1 & 5 & 10 & 18 & $1 \cdot 7 *$ & 1,047 \\
$\begin{array}{c}19 \text { patients given } \\
\text { lysergide }\end{array}$ & 1 & 1 & 1 & 6 & 9 & $0.7 \dagger$ & 1,238 \\
\hline
\end{tabular}

\section{Results}

Five Patients Aged Under 50 Treated with Chlorpromazine. - The frequency of gaps was $12.7 \%$, compared with $6.2 \%$ in the controls $(\mathbf{P}<0.001)$, and the frequency of hypodiploid cells was $4.7 \%$, compared with $1.9 \%$ in the controls $(P<0.01)$.

Eight Patients' Aged 50 or More Treated with Chlorpromazine.-The frequency of breaks was $2.4 \%$, compared with $0.5 \%$ in the controls $(\mathbf{P}<0.025)$.

Ten Patients Aged Under 50 Treated with Perphenazine.The frequency of gaps was $19 \cdot 4 \%$, compared with $6.2 \%$ in the controls $(\mathrm{P}<0.001)$. The frequency of breaks was $3.5 \%$, compared with $0.2 \%$ in the controls $(\mathbf{P}<0.001)$. The frequency of hypodiploid cells was $5 \cdot 2 \%$, compared with $1.9 \%$ in the controls $(\mathrm{P}<0.001)$.

Five Patients Aged 50 or More Treated with Perphenazine. - The frequency of breaks was $4.5 \%$, compared with $0.5 \%$ in the controls $(P<0.001)$, and the frequency of hypodiploid cells was $11.9 \%$, compared with $6.9 \%$ in the controls $(P<0.025)$.

In addition, we made a chromosome study of two patients aged 37 and 41 once before treatment with perphenazine and twice during treatment. Neither of them had any breaks before treatment, but they had from 3.9 to $8.1 \%$ breaks after treatment with from 1.620 to $1.992 \mathrm{mg}$. of perphenazine.

Nine Patients Aged Under 50 Treated with Lysergide.-The frequency of gaps was $18.2 \%$, compared with $6.2 \%$ in the 
controls $(P<0.001)$. The frequency of breaks was $4.3 \%$, compared with $0.2 \%$ in the controls $(P<0.001)$. The frequency of hypodiploid cells was $7.5 \%$, compared with $1.9 \%$ in the controls $(\mathrm{P}<0.001)$. The frequency of hyperdiploid cells was $1.2 \%$ compared with $0.2 \%$ in the controls $(\mathrm{P}<0.025)$.

Ten patients Aged Under 50 Who Took Lysergide for Psychedelic Purpose.-The frequency of breaks was $2.5 \%$, compared with $0.2 \%$ in the controls $(P<0.001)$. The frequency of hypodiploid cells was $5.8 \%$, compared with $1.9 \%$ in the controls $(\mathbf{P}<0.001)$.

Comparison Between Patients Treated with Chlorpromazine and Perphenazine.-Patients below the age of 50 treated with perphenazine had a significantly higher frequency of gaps $(19.4 \%)$ and breaks $(3.5 \%)$ than patients treated with chlorpromazine, who had $12.7 \%$ gaps $(\mathrm{P}<0.01)$ and $1.0 \%$ breaks $(\mathrm{P}<0.05)$. Patients aged 50 or over treated with perphenazine had a significantly higher frequency of hyperdiploid cells $(2.3 \%)$ than patients treated with chlorpromazine with $0.6 \%$ $(\mathbf{P}$ (Fisher) $=0.044)$.

Comparison Between Patients Treated with Chlorpromazine and Lysergide.-Patients below the age of 50 treated with lysergide had a significantly higher frequency of gaps (18.2\%) and breaks $(4.3 \%)$ than patients below the age of 50 treated with chlorpromazine, who had $12.7 \%$ gaps $(\mathrm{P}<0.05)$ and $1.0 \%$ breaks $(\mathrm{P}<0.025)$

Correlation Between Drug Doses, Length of Treatment, Highest Daily Drug Dose, and Frequency of Chromosome Abnormalities. - We found no such correlation in the patients treated with chlorpromazine, but in those under 50 treated with perphenazine a correlation between length of treatment and the total amount of drugs given and the frequency of gaps and breaks did exist. The frequency of gaps in the four patients treated for less than five months and given less than $6 \mathrm{~g}$. of perphenazine was $16.2 \%$, compared with $21.5 \%$ in the three patients treated for 5 to 12 months and given from 6 to $15 \mathrm{~g}$. of perphenazine and $24.0 \%$ in the three patients treated for more than 12 months and given more than $15 \mathrm{~g}$. of perphenazine. The difference between the first and the last group was statistically significant $(P<0.05)$. The frequency of breaks was $4.3 \%, 5.4 \%$, and zero in these three groups. The difference between the first and the last group was statistically significant $(\mathbf{P}($ Fisher $)=0.002)$, and so was the difference between the second and the last group ( $P$ (Fisher) $=$ 0.001 ). The frequency of gaps was similar in patients given below and above $48 \mathrm{mg}$. of perphenazine as the highest daily dose, but the frequency of breaks was 0.6 and $4.5 \%$, respectively, which was statistically significant $(P($ Fisher $)=0.006)$. The three patients aged under 30 given perphenazine in doses varying from 3 to $32 \mathrm{~g}$. had no breaks, whereas those aged 30 to 40 had a break frequency of $4.8 \%$ (P (Fisher) $=$ $0.004)$ and those aged $50+$ a frequency of $4.5 \%$ ( $P$ (Fisher) $=$ $0.001)$.

Dicentric Chromosomes, Ring Chromosomes, and Chromosome Fragments. - Significantly higher total frequencies of chromosome fragments, dicentric chromosomes, and ring chromosomes in patients treated with perphenazine and lysergide occurred compared with the controls $(P<0.001)$ and $(\mathrm{P}<0.05)$, respectively (Table III).

\section{Discussion}

Our findings indicate that perphenazine has a toxic effect on chromosomes producing changes to much the same extent as lysergide. Perphenazine was the only psychotropic drug given, but an anti-Parkinsonian drug, orphenadrine, was as usual given together with it, and a certain synergistic toxic effect of the two drugs may have occurred. The findings further indicate that chlorpromazine has some toxic effect on chromosomes, but not nearly to the extent found with perphenazine and lysergide.

Anders et al. (1968) found a significantly higher frequency of hypermodal cells and acentric chromosome fragments in psychiatric patients, compared with that in a control group. These workers mentioned that these abnormalities might be causally related to the mental illness of these patients. It is, however, more likely that they were due to treatment with psychotropic drugs and not causally related to the mental illness. There is no indication at present of a higher frequency of chromosome abnormalities such as gaps, breaks, or aneuploid cells than is expected in psychiatric patients not treated with psychotropic drugs.

As discussed in several recent papers (Cohen et al., 1967a, 1967b; New England Fournal of Medicine, 1967 ; Irwin and Egozcue, 1967 ; Egozcue et al., 1968 ; Nielsen et al., 1968a) it cannot be excluded that chromosome abnormalities such as breaks, dicentric chromosomes, chromosome fragments, and ring chromosomes may predispose to malignant disorders, and if such chromosome abnormalities are found in meiosis as indicated by the studies of Skakkebæk et al. (1968) and Cohen

TABLE I.-Details of Drugs

\begin{tabular}{|c|c|c|c|c|c|c|c|}
\hline \multirow{2}{*}{ Drug } & \multirow{2}{*}{ No. of cases } & \multicolumn{2}{|c|}{$\begin{array}{c}\text { Duration of Treatment } \\
\text { (months) }\end{array}$} & \multicolumn{2}{|c|}{ Daily Dosage } & \multicolumn{2}{|c|}{ Total Amounts } \\
\hline & & Range & Mean & Highest & Mean & Range & Mean \\
\hline $\begin{array}{l}\text { Chlorpromazine } \\
\text { Perphenazine } \\
\text { Lysergide.. }\end{array}$ & $\begin{array}{r}13 \\
15 \\
9\end{array}$ & $\begin{array}{l}0 \cdot 5-161 \\
1-108 \\
3-39\end{array}$ & $\begin{array}{l}94 \\
25 \\
15\end{array}$ & $\begin{array}{l}125-500 \mathrm{mg} . \\
12-72 \mathrm{mg} . \\
50-750 \mu \mathrm{g} .\end{array}$ & $\begin{array}{l}331 \mathrm{mg} . \\
49 \mathrm{mg} . \\
233 \mu \mathrm{g} .\end{array}$ & $\begin{array}{c}4-1,591 \mathrm{~g} . \\
2-76 \mathrm{~g} . \\
1,940-18,400 \mu \mathrm{g} .\end{array}$ & $\begin{array}{l}702 \mathrm{~g} . \\
19 \mathrm{~g} . \\
6,350 \mu \mathrm{s} .\end{array}$ \\
\hline
\end{tabular}

TABLE II.-Controls and Patients Treated with Chlorpromazine, Perphenazine, and Lysergide Distribution by Age, Gaps, Breaks, Hypodiploid Cells, Hyperdiploid Cells, and Cells Examined

\begin{tabular}{|c|c|c|c|c|c|c|c|c|c|c|}
\hline \multirow{2}{*}{ Patient group } & \multirow{2}{*}{ Age, mean \pm S.D. } & \multicolumn{2}{|c|}{ Gaps } & \multicolumn{2}{|c|}{ Breaks } & \multicolumn{2}{|c|}{ Hypodiploid cells } & \multicolumn{2}{|c|}{ Hyperdiploid cells } & \multirow{2}{*}{$\begin{array}{l}\text { No. of cells } \\
\text { examined }\end{array}$} \\
\hline & & No. & $\%$ & No. & $\%$ & No. & $\%$ & No. & $\%$ & \\
\hline $\begin{array}{l}\text { Age }<50 \\
30 \text { controls } \ldots . \\
5 \text { patients treated with }\end{array}$ & $31 \cdot 4 \pm 9 \cdot 0 \mu$ & 64 & $6 \cdot 2$ & 2 & $0 \cdot 2$ & 20 & 1.9 & 2 & $0 \cdot 2$ & 1,030 \\
\hline $\begin{array}{l}\text { Chlorpromazine } \\
10 \text { patients treated with }\end{array}$ & $32 \cdot 6 \pm 14 \cdot 6 \mu$ & 38 & $12 \cdot 7^{*}$ & 3 & $1 \cdot 0$ & 14 & $4 \cdot 7 t$ & 1 & $0 \cdot 3$ & 299 \\
\hline 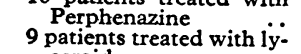 & $32 \cdot 9 \pm 10 \cdot-1$ & 143 & $19 \cdot 4^{*}$ & 26 & $3 \cdot 5^{*}$ & 38 & $5 \cdot 2^{*}$ & 2 & $0 \cdot 3$ & 736 \\
\hline 10 patients who took ly- & $36 \cdot 1 \pm 7 \cdot 2 \mu$ & 110 & $18 \cdot 2^{*}$ & 26 & $4 \cdot 3^{*}$ & 45 & $7 \cdot 5^{*}$ & 7 & $1 \cdot 2+$ & 603 \\
\hline $\begin{array}{lll}\text { sergide } & \cdots & \cdots \\
\text { Age } 50+: & & \end{array}$ & $19 \cdot 8 \pm 3 \cdot 0 \mu$ & 50 & $7 \cdot 9$ & 16 & $2 \cdot 5^{*}$ & 37 & $5 \cdot 8^{*}$ & 2 & $0 \cdot 3$ & 635 \\
\hline $\begin{array}{l}11 \text { controls } \\
8 \text { patients treated with }\end{array}$ & $67 \cdot 0 \pm 8 \cdot 8 \mu$ & 57 & $10 \cdot 3$ & 3 & 0.5 & 38 & $6 \cdot 9$ & 4 & 0.7 & 554 \\
\hline 5 patients treated with & $58 \cdot 8 \pm 6 \cdot-3$ & 68 & $13 \cdot 7$ & 12 & $2 \cdot 4 t$ & 49 & $9 \cdot 9$ & 3 & 0.6 & 495 \\
\hline Perphenazine $\quad$.. & $61 \cdot 6 \pm 5 \cdot 2 \mu$ & 39 & $12 \cdot 5$ & 14 & $4 \cdot 5^{*}$ & 37 & $11.9+$ & 7 & $2 \cdot 3$ & 311 \\
\hline
\end{tabular}


and Mukherjee (1968), it may further have a teratogenic effect, which is also indicated from animal studies by Alexander et al. (1967), Auerbach and Rugowski (1967), and Geber (1967).

A comparatively low frequency of chromosome abnormalities, such as gaps and breaks, may have no deleterious effect on the organism or on the offspring. On the other hand, a higher frequency of breaks with fragments, dicentric chromosomes, ring chromosomes, translocations, and aneuploid cells may be associated with mutations and probably predispose to malignant disorders and an increased risk of abortions, chromosome abnormalities, and congenital abnormalities in the offspring.

If certain drugs induce quite extensive chromosome abnormalities like perphenazine and lysergide, and if other drugs with a similar therapeutic effect have a considerably less toxic effect on chromosomes, then it would seem advisable not to use the more toxic drugs until further studies concerning the risks of such toxic chromosome abnormalities as found in patients treated with lysergide and perphenazine have been made.

\section{REFERENCES}

Alexander, G. J., Miles, B. E., Gold, G. M., and Alexander, R. B. (1967).

Science, 157, 459.
Anders, J. M., Jagiello, G., Polani, P. E., Giannelli, F., Hamerton, J. L., (1968). British fournal of Psychiatry, 114 1167 .

Auerbach, R., and Rugowski, J. A. (1967). Science, 157, 1325. Cohen, M. M., Hirschhorn, K., and Frosch,

England Fournal of Medicine, 277, 1043. ${ }^{2}$. (1967b). Science, 155, 1417 .

Cohen, M. M., and Mukheriee, A. B. (1968). Nature, 219, 1072.

Court Brown, W. M., Buckton, K. E., Jacobs, P. A., Tough, I. M., Kuenssberg, E. V.o and Knox, J. D. E. (1966). Chs

Studies on Adults. London, Cambridge University Press.
(1968). Fournal of the American Medical Association, 204, 214.

Geber, W. F. (1967). Science, 158, 265.

Irwin, S., and Egozcue, J. (1967). Science, 157, 313.

New England fournal of Medicine, 1967, 277, 1090.

Nielsen J, Friedrich, U., Jacobsen, E., and Tsuboi, T. (1968a). British Medical fournal, 2, 801.

Medical fournal, 2,

Nielsen, J., Friedrich, U., and Tsuboi, T. (1968). (1968). Science, 160, 1246 .

\section{Medical Memoranda}

\section{Massive Pulmonary Haemorrhage in the Newborn Associated with Coxsackie B Virus Infection}

\author{
British Medical Fournal, 1969, 3, 636-637
}

So far as we are aware Coxsackie viral infections have not been previously reported in association with massive pulmonary haemorrhage of the newborn, though neonatal myocarditis due to Coxsackie viruses has been described (Verlinde et al., 1956).

\section{CASE REPORT}

This female child was born at 41 weeks after an apparently uncomplicated pregnancy and labour. She was normal at birth (weight 3,700 g.) and for seven days her progress was uneventful. On the eighth day she had rapid respiration without cyanosis, and some rib recession was noted. The chest $x$-ray picture was normal. A systolic murmur developed and there was fever up to $100 \cdot 4^{\circ} \mathrm{F}$. $\left(38^{\circ}\right.$ C.). Early heart failure was suspected, and the baby was treated with digoxin and Ampiclox (ampicillin and cloxacillin). Terminally, she had two large haemoptyses and died on the eighth day.

Necropsy was performed 31 hours after death. The principal findings were massive pulmonary haemorrhage, acute myocarditis, and meningoencephalitis. Because of their intrinsic interest and the rarity of massive pulmonary haemorrhage in the newborn, the results of the examination of the respiratory, cardiovascular, and central nervous systems are reported.

The trachea and main bronchi contained a little frothy blood. The lungs (left, $53 \mathrm{~g}$.; right, $64 \mathrm{~g}$.) were very congested. They sank in saline with partial floating beneath the surface. The anterior periphery had areas with a little aeration. The appearances on slicing suggested that the lungs were full of blood, but there was no obvious pus. The pleural cavities were clean. Histologically the picture was similar throughout all lobes; there was massive haemorrhage throughout the airways. Strands of fibrin were present in places containing enmeshed red blood cells. The fibrin in some areas resembled the hyaline membrane material, and was seen in alveolar ducts and within the lumen of bronchioles together with red cells. There were also groups of macrophages in some areas where the haemorrhage was not pronounced. There was no evidence of any polymorph infiltration or other indication of inflammatory changes in the lung parenchyma, but the pleura in several sections showed infiltration by mononuclear cells with occasional polymorphs. A few red blood cells were also present. The heart was not remarkable macroscopically, but sections of the left ventricle and atrium showed a patchy infiltration of the myocardium by large mononuclear cells and polymorphs. The right ventricle and atrium appeared normal, and there were no areas of haemorrhage or necrosis to suggest infarction. The brain showed some generalized swelling of the cerebral hemispheres without opacity of the meninges. Sections of the brain and spinal cord showed some increase of mononuclear cells with a few polymorphs in the subarachnoid space. Viral inclusion bodies were not identified in any of the tissues.

Cultures of heart blood, the bronchial swab, and a swab from the right lower pulmonary lobe were sterile. Examination of about $15 \mathrm{ml}$ of colourless slightly turbid cerebrospinal fluid taken at necropsy gave the following results: sugar $52 \mathrm{mg} . / 100 \mathrm{ml}$., chloride $95 \mathrm{mg} . / 1$., protein $250 \mathrm{mg} . / 100 \mathrm{ml}$.; cell count (cells degenerate, aproximate counts only); leucocytes $1,150 / \mathrm{cu}$. mm., erythrocytes $160 / \mathrm{cu} . \mathrm{mm}$; stained films: Gram, no organisms seen, Leishman, $160 / \mathrm{cu}$. mm. ; stained flls, lymphocytes, and, rather more frequently, polymorphonuclear leucocytes. These findings suggested aseptic meningitis. Histological examination some days after necropsy meningitis. Histological exam Deep-frozen liver, the only tissue still available for microbiological examination, was sent to Dr. D. Gamble, who isolated Coxsackie virus type B2.

\section{COMMENT}

The incubation period for Coxsackie virus infections is usually two to five days but may be as long as two weeks (MacCallum, 1961). As the illness occurred on the eighth day of life it was not possible to determine whether the infection was prenatally or postnatally acquired. There was no maternal history of infection. Coxsackie virus types B1-5 are associated with aseptic meningitis, though meningoencephalitis and myocarditis have been described (Verlinde et al., 1956 ; Gear and Measroch, 1958). In the present case mononuclear cell infiltration of the pleura suggested a more widespread dissemination of the virus with pleurisy, and the possibility of a postnatally acquired respiratory tract infection cannot be excluded. Respiratory tract infection, heart failure, and cerebral oedema are all factors known to be associated with pulmonary oedema and haemorrhage. 